\title{
Status of invasive alien plant species in Urban Forest of Hetauda, Nepal
}

\author{
Kabita Pandey ${ }^{1 *}$, Gayatri Paudel ${ }^{1}$, Ashish Neupane ${ }^{2}$, Keshav Raj Acharya ${ }^{1}$ \\ and Subash Adhikari ${ }^{1}$ \\ 1 Institute of Forestry Hetauda Campus, Hetauda \\ 2 Institute of Forestry, Pokhara Campus, Pokhara
}

\section{KEYWORDS}

Diversity

Invasive alien plant species

Relative abundance

Transect survey

Nepal

\begin{abstract}
This paper explores the status of Invasive Alien Plant Species in an urban forest of Hetauda, Nepal. The study is based on a quadrate survey (130 quadrants) within the transect line at an interval of $30 \mathrm{~m}$ within different six habitat types. This study identified a total of 22 invasive alien plant species representing 20 genera and 12 families out of recorded 26 species representing 24 genera and 15 families in the country. This study identified four species namely Chromolaena odorata, Eichhornia crassipes, Lantana camara and Mikania micrantha in the study area that were listed as the world's 100 worst invasive species. The invasion was found to be negatively correlated with canopy cover. The higher the canopy cover; the lower the abundance of invasive alien species. Regarding the habitat type, settlement area had the highest number of invasive species followed by forest and roadside. Mikania micrantha, Lantana camara, Ageratum houstonianum and Chromolaena odorata were mostly abundant in forest whereas Eichhornia crassipes was highly abundant in wetlands. Mikania micrantha was mostly abundant in settlement area and Senna tora was confined to open land. The relative abundance of Ageratum conyzoides, Senna occidentalis, Ageratum adenophora, Leersia hexandra, Mimosa pudica, Bidens pilosa, Oxalis latifolia, Ipomoea carnea, Amaranthus spinosus, Argemone mexicana, Esosphaerum suaveolens were lower.
\end{abstract}

\section{Introduction}

Invasive alien species (IAS) are introduced species of exotic (non-native species of plant or animal) origin that causes harm to the health and function of the invaded ecosystem (Lelmini and Shankaran 2021). IAS are generally introduced either intentionally or by accident and spread from human settings in nature and causing harm to the environment, ecosystem, and human well-being (Ehrenfeld 2010). IAS includes both non-native invasive plant and animal species. However, invasive alien plant species has been focussed on by scholars in Nepal (Tiwari et al. 2005; Shrestha 2016; Pathak et al. 2021) in comparison to invasive alien

\footnotetext{
* Corresponding author

E-mail address: pandeykabita743401@gmail.com

Received 6 July 2021 Accepted 25 November 2021
} 
animal species (Budha 2013). Invasive alien plant species (IAPS) are characterized by a short life cycle, a fast growth rate, a large number of seeds with good dispersal ability, and a good colonizing capacity (Bisht et al. 2016). When IAPS is introduced to new communities, it alters the structure and function of the ecosystem leading to a major threat to native plant communities and even causing major changes in vegetation at the global level (Mack et al. 2000). Human influence often contributes to the disturbance of habitats, making them more susceptible to invasion, facilitating many alien plants by freeing nutrients, and by changing natural disturbance regimes (Davis et al. 2000).

The first study regarding invasive alien species in the country was conducted by M.L. Banerji in 1958 through the study Invasion of Eupatorium glandulosum in Eastern Nepal (Ghimire et al. 2020). A detailed study conducted by IUCN listed 21 different IAPS in the country (Tiwari et al. 2005). The number reached 25 during the study conducted by Shrestha, 2016. Department of Plant Resources have listed 26 different IAPS in 2020 (Ghimire et al. 2020). This scenario confirms that the invasion of IAPS in Nepal has been increased in recent years.

Most of the alien plant species are found in the Terai, Siwalik, and Mid-hills of Nepal as more than three-fourth of IAPS recorded in Nepal are native to tropical and subtropical regions of the world (Tiwari et al. 2005). Among the 100 worst invasive plant species of the world (Lowe et al. 2000), 11 plant species are found in Nepal (Shrestha 2016). Sankaran et al. 2005 identified Ageratina adenophora, Ageratum conyzoides, Chromolaena odorata, Eichhornia crassipes, Lantana camara, Mikania micrantha and Parthenium hysterophorus as the most problematic IAPS for Indian forests; all these species have been recorded in Nepal (Shrestha 2016).

In Nepal, most of the studies regarding IAPS have been confined to ecological studies on wetland and protected areas (Pandey et al. 2020). Limited research and case studies carried out in the country mostly focused on habitat degradation of endangered wildlife (Murphy et al. 2013) and negative effects on the livelihoods of rural communities (Rai et al. 2012). Murphy et al. (2013) reported that $44 \%$ of the habitat of endangered one-horned rhinoceros in Chitwan National Park has been negatively affected by Mikania micrantha by suppressing the growth of grasses and regeneration of trees. Another IAPS Parthenium hysterophorus has significantly altered species composition and soil chemistry of grasslands (Timsina et al. 2011). The invasion of IAPS in urban and semiurban areas has been prioritized in different parts of the world (Stajerova et al. 2017). Cadotte et al. (2017) reported that alien species richness generally increases with urbanisation. Pathak et al. 2021 has also concluded that urban areas provides suitable microhabitats for the establishment of IAPS that subsequently disseminate their propagules for wider spread into the surrounding landscapes. Hetauda city, located between two protected areas (Chitwan and Parsa National Parks) within Siwalik range and connecting hilly region with the Terai through road connectivity, is in the stage of rapid urbanization after its declaration as the provincial capital of Bagmati province. In recent years, different species of IAPS have been observed threatening biodiversity in the area by reducing the regeneration of native species; however, no systematic study regarding the status of invasive alien plant species has been conducted outside the protected areas, particularly in vicinity of urban forest has been conducted so far. This study was conducted in an urban forest of Hetauda to identify the status of IAPS respective to different habitat type.

\section{Methods and Materials}

\section{Study Area}

This study was conducted in Institute of Forestry (IOF), Hetauda which is surrounded by urban settlement of Hetauda Sub-Metropolitan City that is the provincial headquarter of Bagmati province, Nepal, between the latitude of $27^{\circ} 21^{\prime}$ - 


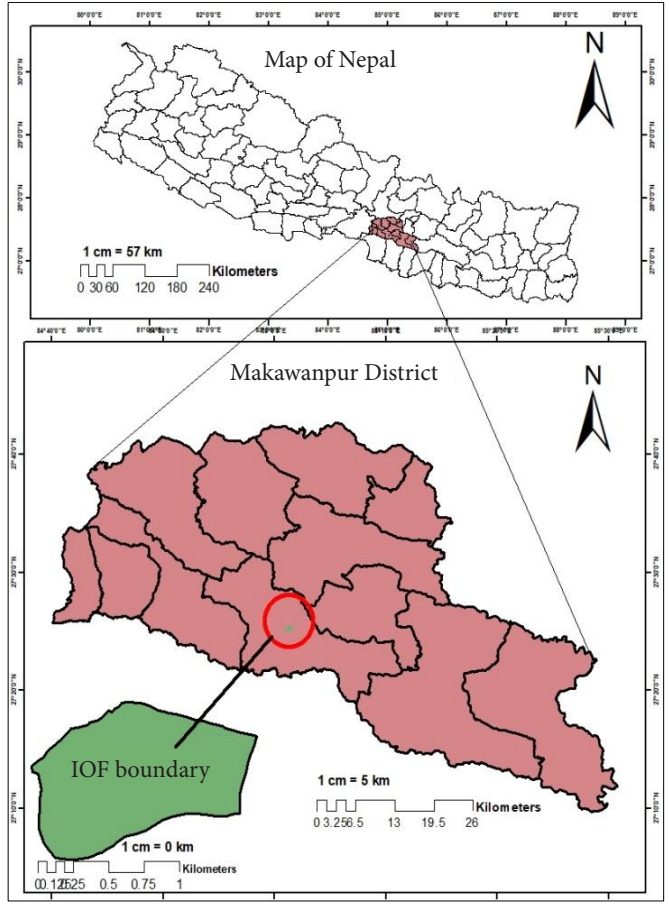

Figure 1: Location Map of Study Area

$27^{\circ} 40^{\prime} \mathrm{N}$ and longitude of $84^{\circ} 41^{\prime}-84^{\circ} 35^{\prime} \mathrm{E}$. Hetauda is located in the sub-tropical climatic zone with the mean monthly maximum and minimum temperatures of $29^{\circ} \mathrm{C}$ and $17^{\circ} \mathrm{C}$ and annual rainfall of $2125 \mathrm{~mm}$ (Maraseni et al. 2008).

The total area of the campus premises was 102.57 ha which is bordered by Karra River in the south, Bhutandevi temple and settlement in the North, east-west highway in the East, and Rapti River in the West. The forest consists mainly of 4 habitat types namely, forest land, wetland, grassland, and open land. Similarly, some areas have been allocated for residential purposes. The premises support a wide range of flora and fauna. The forest is subtropical type dominated by Shorea robusta, Bombax ceiba, Schima wallichii, Gmelina arborea, Albizia lebbeck, Trewia nudiflora, Syzygium cumini, and planted forest of Eucalyptus species. Grassland consists of Imperata cylindrica and Saccharum spontaneum. In recent years different species of IAPS have been observed threatening biodiversity in the area through reducing the regeneration of native species.

\section{Data Collection}

After the preliminary visit, the forest was divided into different habitat types using Google Earth and ArcGIS 4.1 software. Identified major habitat types were forest area, wetland, grassland and open land. Similarly, some areas have been occupied by settlement and road network. So, the forest was divided into six different habitat types namely, forest land, wetland, grassland, settlement area, roadside and open land for the study purpose. Wetlands cover the riversides as well as the swampy and marshy areas. Similarly, forest area includes all natural and plantation plots as well as degraded forest. In between the forest and settlement, the playground and its surroundings were classified as open land. Road side were considered as separate habitat types for the study purpose. Among all habitat types, forest area covers the largest area (74.55 ha) followed by settlement area ( $8.88 \mathrm{ha})$, wetland ( $8.80 \mathrm{ha})$, grassland (6.84 ha), and open land (2.48 ha). Roadside (1.02 ha) covers the smallest area.

A total of 26 transect lines were placed at a minimum interval of $300 \mathrm{~m}$ covering all land use types. A total of 15 transects were placed in the forest area and 2 transects each were placed in the remaining habitat types except the roadsides. On the roadside, 3 transects were placed as the length of the road was more than 3 kilometres within the whole premises. Figure 2 shows the location of the transect line within the different parts of the area.

A transect walk was carried out and samples of different plant species were collected and tallied with the reference of previous report (Tiwari et al. 2005; Shrestha 2016; Ghimire et al. 2020). Frequencies and distribution of each identified IAPS for separate habitat type were counted in quadrates of $1 \mathrm{~m} 2$ (size $1 \mathrm{~m} \times 1 \mathrm{~m}$ ) and $4 \mathrm{~m} 2$ (size $2 \mathrm{~m} \times 2 \mathrm{~m}$ ) that were placed at an interval of $30 \mathrm{~m}$ for herbs and shrub species, respectively. Each transects consists of 5 quadrats, thus the whole study area consists of 26 transect lines 


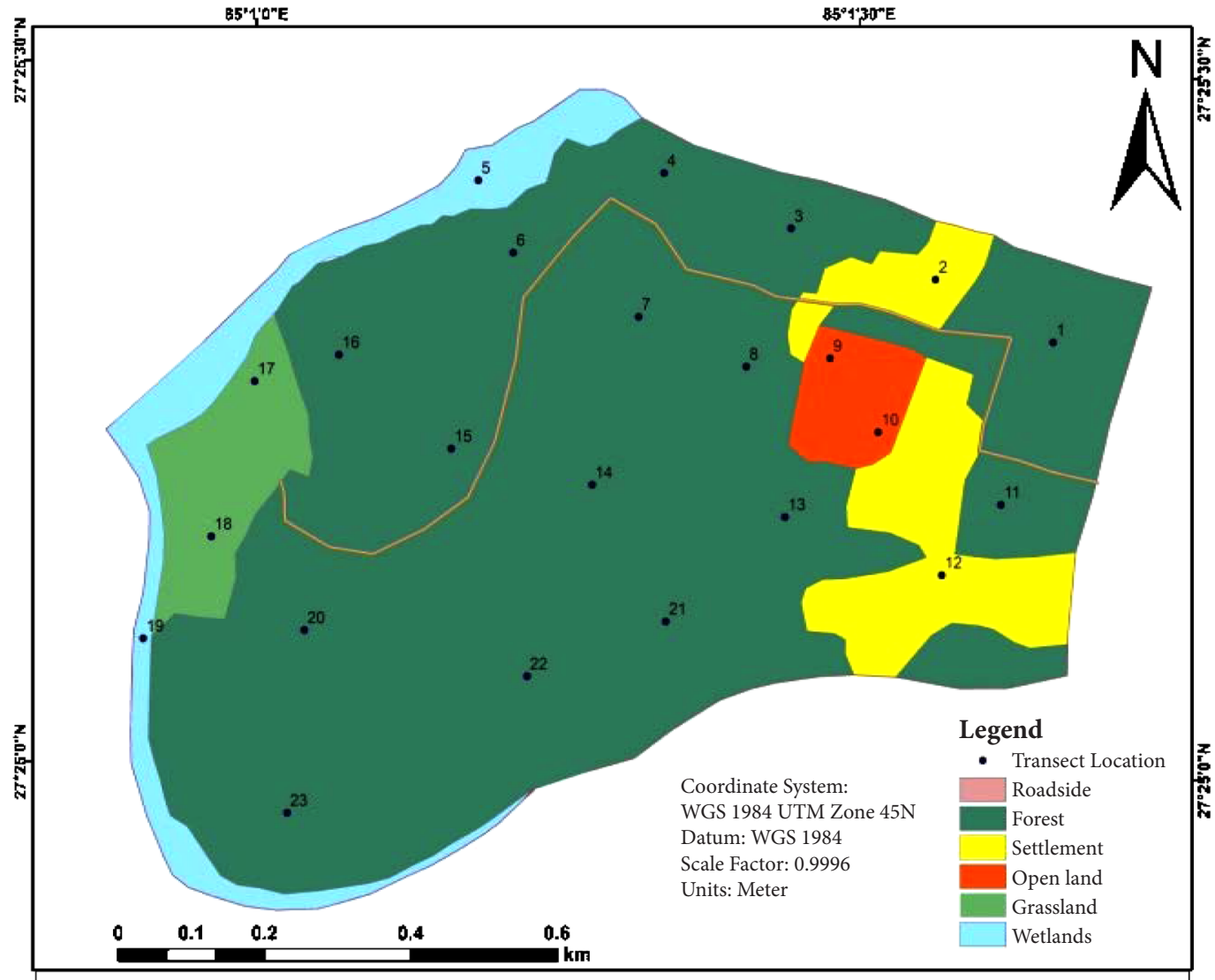

Figure 2: Location of the transect line within the different parts of the area

and 130 quadrates. The survey was conducted in December 2020 and again in June 2021 so that the vegetation of both winter and rainy season could be surveyed.

\section{Data Analysis}

Based on an inventory of the located quadrats, Relative Density (RD in \%) and Relative Frequency (RF in \%), and Relative Abundance (RA in \%) were calculated to calculate IVI for each species using the following formula.

Relative Frequency $($ RF, \% $)=$

$\frac{\text { Frequency of individual species }}{\text { Sum of the frequencies for all species }}$ X 100

Relative Density $(\mathrm{RD}, \%)=$
Relative Abundance (RA, \%) =

$\frac{\text { Abundance of individual species }}{\text { Total abundance of all species }}$ X 100

Importance value index $(\mathrm{IVI})=\mathrm{RF}+\mathrm{RD}+\mathrm{RA}$

\section{Results and Discussions}

\section{List of the IAPS}

A total of 22 IAPS belonging to 12 families and 20 genera were recorded in the area. Most of the recorded IAPS belonged to the Asteraceae family ( 9 species) followed by Amaranthaceae ( 3 species). Two were from Caesalpiniaceae family. The remaining species represented to singlefamily. Two genera (Senna and Ageratum) had two species each and rests were from separate genera (Table 1). 
Table 1: Identified Invasive Alien Plant Species

\begin{tabular}{|c|c|c|c|c|c|}
\hline S.N & Common Name & Local Name & Scientific Name & Family & Habitat type \\
\hline 1. & $\begin{array}{l}\text { Mile-a-minute } \\
\text { weed }\end{array}$ & Lahare banmara & $\begin{array}{l}\text { Mikania } \\
\text { micrantha }\end{array}$ & Asteraceae & FL, SA, RA \\
\hline 2. & Lantana & Kirne kanda & Lantana camara & Verbenaceae & $\begin{array}{l}\text { FL, GL, SA, } \\
\text { RA }\end{array}$ \\
\hline 3. & Siam weed & Seto Banmara & $\begin{array}{l}\text { Chromolaena } \\
\text { odorata }\end{array}$ & Asteraceae & FL, SA, RA \\
\hline 4. & Parthenium & Patijhar & $\begin{array}{l}\text { Parthenium } \\
\text { hysterophorus }\end{array}$ & Asteraceae & $\begin{array}{l}\text { SA, OL, WL, } \\
\text { RA }\end{array}$ \\
\hline 5. & Coffee Senna & Panwar & Senna occidentalis & Caesalpiniaceae & $\mathrm{FL}$ \\
\hline 6. & Spiny pigweed & Kandelude & $\begin{array}{l}\text { Amaranthus } \\
\text { spinosus }\end{array}$ & Amaranthaceae & OL, SA \\
\hline 7. & $\begin{array}{l}\text { Black jack/Hairy } \\
\text { Beggar-tick }\end{array}$ & Kalo kuro & Bidens pilosa & Asteraceae & $\mathrm{GL}, \mathrm{SA}, \mathrm{OL}$ \\
\hline 8. & Sicklepod senna & Tapre & Senna tora & Caesalpiniaceae & $\begin{array}{l}\text { FL, GL, SA, } \\
\text { OL, RA }\end{array}$ \\
\hline 9. & Bushmint & Tulsi Jhar & $\begin{array}{l}\text { Mesosphaerum } \\
\text { suaveolens }\end{array}$ & Lamiaceae & RA \\
\hline 10. & Sensitive plant & Lajjawati & Mimosa pudica & Mimosaceae & GL, SA, WL \\
\hline 11. & Billygoat & Raunne /Gandhe & $\begin{array}{l}\text { Ageratum } \\
\text { conyzoides }\end{array}$ & Asteraceae & $\mathrm{FL}$ \\
\hline 12. & $\begin{array}{l}\text { Blue Billygoat } \\
\text { Weed }\end{array}$ & Nilogandhe & $\begin{array}{l}\text { Ageratum } \\
\text { houstonianum }\end{array}$ & Asteraceae & $\begin{array}{l}\text { FL, GL, SA, } \\
\text { WL, RA }\end{array}$ \\
\hline 13. & Water hyacinth & Jalkumbhi & $\begin{array}{l}\text { Eichhornia } \\
\text { crassipes }\end{array}$ & Pontederiaceae & WL \\
\hline 14. & $\begin{array}{l}\text { Bush morning- } \\
\text { Glory }\end{array}$ & Besharam & Ipomoea carnea & Convolvulaceae & SA \\
\hline 15. & Alligator weed & Jala jambhu, & $\begin{array}{l}\text { Alternanthera } \\
\text { philoxeroides }\end{array}$ & Amaranthaceae & WL \\
\hline 16. & Rough cockle-Bur & Bhede kuro & $\begin{array}{l}\text { Xanthium } \\
\text { strumarium }\end{array}$ & Asteraceae & GL \\
\hline 17. & Purple wood sorrel & Chari amilo & Oxalis latifolia & Oxalidaceae & SA \\
\hline 18. & Crofton weed & Kalo Banmara & $\begin{array}{l}\text { Ageratina } \\
\text { adenophora }\end{array}$ & Asteraceae & FL \\
\hline 19. & Southern Cut grass & $\begin{array}{l}\text { Karaute ghans, Navo } \\
\text { dhan }\end{array}$ & Leersia hexandra & Poaceae & FL, SA, WL \\
\hline 20. & Water lettuce & Kumbhika, Panibanda & Pistia Stratiotes & Araceae & $\mathrm{WL}$ \\
\hline 21. & Mexican poppy & Thakal & $\begin{array}{l}\text { Argemone } \\
\text { mexicana }\end{array}$ & Papaveraceae & SA \\
\hline 22. & Shaggy Soldier & Jhuse Chitlange & $\begin{array}{l}\text { Galinsoga } \\
\text { quadriradiata }\end{array}$ & Asteraceae & RA \\
\hline
\end{tabular}

Note: $\mathrm{FL}=$ Forest Land, $\mathrm{WL}=$ Wetland, GL= Grassland, $\mathrm{SA}=$ Settlement Area, $\mathrm{RA}=$ Roadside Area, $\mathrm{OL}=\mathrm{Open}$ land 
Regarding the habitat type, the maximum number of species (12 species) was recorded in the settlement area followed by the forest area (9 species). Eight species were recorded from roadside. Seven species were recorded in wetland and 6 species in grassland. Similarly, open land had the least species richness (5 species). Some species were only confined to particular habitat type. Eichhornia crassipes, Alternanthera philoxeroides and Pistia stratiotes were recorded only in wetland whereas Ageratum conyzoides, Ageratina adenophora and Senna occidentalis were recorded only in forest land. Similarly, Ipomoea carnea, Oxalis latifolia and Argemone mexicana were only recorded in settlement area. Galinsoga quadriradiata and Mesosphaerum suaveolens were only recorded in road side. Four species (Ageratum houstonianum, Lantana camara, Parthenium hysterophorus and Senna tora) were found widely distributed in more than four habitat types.

Regarding the seasonal variations, seventeen species were recorded in winter survey and additional five species namely; Galinsoga quadriradiata, Bidens pilosa, Oxalis latifolia, Ageratina adenophora, and Amaranthus spinosus were recorded in second survey.

\section{Distribution of IAPS}

The distribution of IAPS was found differently as per the habitat type. Some species were only recorded in specific habitat. Distribution of IAPS in respect to habitat type was found as follows;

\section{Forest area}

A total of 9 species were recorded from the forest. Abundance of the IAPS was higher in degraded area. Mikania micrantha, Chromolaena odorata, Lantana camara, Ageratum houstonianum and A. conyzoids were major IAPS recorded in forest. Ageratum houstonianum and A. conyzoids were found highly invaded under the high tension line of electricity transmission where over story vegetation was totally absent.

Senna tora, Senna occidentalis and Leersia hexandra were limited only in the areas with high level of anthropogenic disturbances mostly to the peripheral area. Ageratina adenophora has very limited distribution confined to the degraded forest near the settlement area.

Table 2 shows that Mikania micrantha has the highest IVI (55.47) followed by Chromolaena odorata (45.53), Lantana camara (38.32), and Ageratum houstonianum (37.23). It means these species were found highly distributed in forest areas. Ageratina adenophora has very limited distribution in the study area particularly confined to a degraded forest.

\section{Wetlands}

Altogether seven species were identified in wetland. Highest invasion was observed by Eichhornia crassipes (IVI $=60.27$ ) followed by Alternanthera philoxeroides (IVI= 60.03).

Table 2: IAPS found in Forest Land

\begin{tabular}{|c|c|c|c|c|}
\hline \multirow{2}{*}{ Species } & \multicolumn{4}{|c|}{ Forest land } \\
\hline & RD & RF & RA & IVI \\
\hline Mikania micrantha & 9.49 & 25.37 & 20.62 & 55.47 \\
\hline Chromolaena odorata & 10.66 & 11.71 & 23.17 & 45.53 \\
\hline Lantana camara & 6.54 & 17.56 & 14.22 & 38.32 \\
\hline Ageratum houstonianum & 15.59 & 13.17 & 8.47 & 37.23 \\
\hline Ageratum conyzoides & 21.88 & 2.93 & 11.89 & 36.69 \\
\hline Senna tora & 10.48 & 10.24 & 5.69 & 26.42 \\
\hline Senna occidentalis & 13.24 & 3.41 & 7.19 & 23.85 \\
\hline Leersia hexandra & 10.81 & 2.44 & 5.87 & 19.12 \\
\hline Ageratina adenophora & 1.32 & 13.17 & 2.88 & 17.37 \\
\hline
\end{tabular}


Table 3: IAPS observed in Wetland

\begin{tabular}{lcccc}
\hline \multicolumn{1}{c}{ Species } & RD & RF & RA & IVI \\
\hline Eichhornia crassipes & 23.06 & 15.38 & 21.82 & 60.27 \\
Alternanthera philoxeroides & 21.62 & 17.95 & 20.46 & 60.03 \\
Ageratum houstonianum & 20.27 & 20.51 & 19.18 & 59.96 \\
Pistia stratiotes & 13.51 & 10.26 & 12.79 & 36.56 \\
Leersia hexandra & 11.35 & 10.26 & 10.74 & 32.35 \\
Mimosa pudica & 2.88 & 15.38 & 2.73 & 21.00 \\
Parthenium hysterophorus & 5.41 & 5.13 & 5.12 & 15.65 \\
\hline
\end{tabular}

Similarly, Ageratum houstonianum (IVI= 59.96) was also found abundant in the area. Other minor IAPS recorded in wetlands were Mimosa pudica (IVI = 20.99) and Parthenium hysterophorus (IVI = 15.65).

\section{Grassland}

The western part of the study area consists of the grassland habitat near to wetlands. A small area ( $6.84 \mathrm{ha})$ is covered by Grasslands and consists of Imperata cylindrica and Saccharum spontaneum which are the major grass species in lowland Nepal. A total of six species were recorded in grassland and among them, Ageratum houstonianum (IVI=60.79), Senna tora (IVI=56.71), Xanthium strumarium $(\mathrm{IVI}=48.34)$ and Mimosa pudica $(\mathrm{IVI}=48.23)$ were major while Bidens pilosa $(\mathrm{IVI}=46.58)$ and Lantana camara (IVI=39.35) have minimum distribution. All these species were also recorded by Shrestha (2016) on grassland habitats of Chitwan National Park with the highest distribution of Parthenium hysterophorus. However, Parthenium hysterophorus was not recorded in grass land in this study.

\section{Open land}

Altogether, 5 different species of IAPS were recorded in the open area. Among them, Senna tora has a higher invasion with the highest important value index (IVI) of 68.70. The second higher invasion was created by Parthenium hysterophorus (IVI= 66.58) followed by Bidens pilosa (IVI=65.60), Amaranthus spinosus (IVI=61.30), and Argemone mexicana (IVI=37.83) respectively.

\section{Roadsides}

During preliminary surveys, numbers of IAPS were observed in and around the roadsides. Altogether, 8 species were recorded on the roadsides. The invasion of Mikania micrantha (IVI=56.88) was found higher in the roadside area followed by Chromolaena odorata $(\mathrm{IVI}=47.32)$ and Lantana camara (IVI=43.98). Though the invasion of Parthenium hysterophorus and Mesophaerum suaveolens was found relatively lesser than others, they were seen frequently during the transect survey. Galinsoga quadriradiata was observed limited in number. The invasion is increasing day by

Table 4: IAPS observed in Grassland

\begin{tabular}{lcccc}
\hline \multicolumn{1}{c}{ Species } & RD & RF & RA & IVI \\
\hline Ageratum houstonianum & 24.23 & 20 & 16.56 & 60.79 \\
Senna Tora & 26.26 & 12.5 & 17.94 & 56.71 \\
Xanthium strumarium & 8.26 & 17.5 & 22.58 & 48.35 \\
Mimosa pudica & 15.29 & 22.5 & 10.44 & 48.23 \\
Bidens pilosa & 18.76 & 15 & 12.82 & 46.58 \\
Lantana camara & 7.19 & 12.5 & 19.65 & 39.35 \\
\hline
\end{tabular}


Table 5: IAPS Recorded in Open land

\begin{tabular}{lcccc}
\hline \multicolumn{1}{c}{ Species } & RD & RF & RA & IVI \\
\hline Senna tora & 16.17 & 36.36 & 16.17 & 68.70 \\
Parthenium hysterophorus & 28.74 & 9.09 & 28.74 & 66.58 \\
Bidens pilosa & 19.16 & 27.27 & 19.16 & 65.60 \\
Amaranthus spinosus & 21.56 & 18.18 & 21.56 & 61.30 \\
Argemone mexicana & 14.37 & 9.09 & 14.37 & 37.83 \\
\hline
\end{tabular}

day but no actions have been made to date for their proper management and eradication.

\section{Settlement Area}

The maximum number of IAPS was rerecorded in the settlement area. A total of 12 species were recorded in the settlement area. The invasion of Mikania micrantha (IVI=42.91) was highest around the settlement area followed by Ageratum houstonianum $(\mathrm{IVI}=36.81)$ and Chromolaena odorata (IVI=35.72) respectively whereas Amaranthus spinosus (IVI=16.14) and Leersea hexandra (IVI=12.58) were the least abundant IAPS. There was a nearly equal distribution of Oxalis latifolia (IVI=21.84), Bidens pilosa (IVI=21.28), and Cassia tora $(\mathrm{IVI}=21.06)$ around the area.

\section{Status of IAPS}

Table 8 shows that Mikania micrantha, Chromolaena odorata, Lantana camara, Ageratum houstonianum and Senna tora were the most invasive IAPS in the study area that had the highest values of IVI and relative frequencies. Few species such as Argemone mexicana, Galinsoga quadriradiata and Mesosphaerum suaveolens had the least IVI value and the relative frequencies were less

Table 6: IAPS Recorded in Roadsides

\begin{tabular}{lcccc}
\hline \multicolumn{1}{c}{ Species } & RD & RF & RA & IVI \\
\hline Mikania micrantha & 20.38 & 16.13 & 20.38 & 56.88 \\
Chromolaena odorata & 13.98 & 19.35 & 13.98 & 47.32 \\
Lantana camara & 10.70 & 22.58 & 10.70 & 43.98 \\
Senna tora & 14.98 & 12.90 & 14.98 & 42.87 \\
Ageratum houstonianum & 12.99 & 9.68 & 12.99 & 35.65 \\
Mesosphaerum suaveolens & 8.99 & 12.90 & 8.99 & 30.88 \\
Parthenium hysterophorus & 11.99 & 3.23 & 11.99 & 27.20 \\
Galinsoga quadriradiata & 5.99 & 3.23 & 5.99 & 15.21 \\
\hline
\end{tabular}

Table 7: IAPS Recorded in Settlement Area

\begin{tabular}{lcccc}
\hline Species & RD & RF & RA & IVI \\
\hline Mikania micrantha & 16.91 & 9.89 & 16.12 & 42.91 \\
Ageratum houstonianum & 9.28 & 18.68 & 8.85 & 36.81 \\
Chromolaena odorata & 13.78 & 8.79 & 13.14 & 35.72 \\
Lantana camara & 9.87 & 15.38 & 9.41 & 34.67 \\
Parthenium hysterophorus & 11.17 & 8.79 & 10.65 & 30.60 \\
Oxalis latifolia kunth & 3.87 & 14.29 & 3.69 & 21.84 \\
Bidens pilosa & 9.77 & 2.20 & 9.32 & 21.28 \\
Senna tora & 6.28 & 8.79 & 5.99 & 21.06 \\
Ipomoea carnea & 9.07 & 2.20 & 8.65 & 19.92 \\
Mimosa pudica & 5.82 & 6.59 & 5.55 & 17.95 \\
Amaranthus spinosus & 4.89 & 6.59 & 4.66 & 16.14 \\
Leersia hexandra & 4.19 & 4.40 & 3.99 & 12.58 \\
\hline
\end{tabular}


Table 8: Status of IAPS

\begin{tabular}{lccccc}
\hline Species & RD & RF & RA & IVI & Rank \\
\hline Mikania micrantha & 12.22 & 19.03 & 6.597 & 37.84 & 1 \\
Chromolaena odorata & 16.89 & 8.41 & 9.119 & 34.42 & 2 \\
Lantana camara & 10.88 & 13.72 & 5.875 & 30.47 & 3 \\
Ageratum houstonianum & 2.33 & 13.94 & 5.042 & 21.31 & 4 \\
Senna tora & 5.36 & 10.18 & 2.896 & 18.44 & 5 \\
Ipomoea carnea & 11.21 & 0.44 & 6.055 & 17.71 & 6 \\
Eichhornia crassipes & 4.60 & 1.33 & 9.936 & 15.86 & 7 \\
Xanthium strumarium & 9.12 & 1.55 & 4.924 & 15.59 & 8 \\
Alternanthera philoxeroides & 4.31 & 1.55 & 9.315 & 15.18 & 9 \\
Parthenium hysterophorus & 2.55 & 2.88 & 5.518 & 10.95 & 10 \\
Senna occidentalis & 5.92 & 1.55 & 3.194 & 10.66 & 11 \\
Pistia stratiotes & 2.70 & 0.88 & 5.822 & 9.40 & 12 \\
Ageratum conyzoides & 2.44 & 1.33 & 5.279 & 9.05 & 13 \\
Mimosa pudica & 1.13 & 4.65 & 2.440 & 8.22 & 14 \\
Ageratina adenophora & 0.59 & 5.97 & 1.277 & 7.84 & 15 \\
Leersia hexandra & 1.56 & 2.88 & 3.368 & 7.80 & 16 \\
Bidens pilosa & 1.23 & 3.10 & 2.662 & 6.99 & 17 \\
Oxalis latifolia & 1.19 & 2.88 & 2.580 & 6.65 & 18 \\
Amaranthus spinosus & 1.16 & 2.21 & 2.515 & 5.89 & 19 \\
Mesosphaerum suaveolens & 1.29 & 0.88 & 2.795 & 4.97 & 20 \\
Galinsoga quadriradiata & 0.86 & 0.22 & 1.863 & 2.95 & 21 \\
Argemone mexicana & 0.43 & 0.44 & 0.932 & 1.81 & 22 \\
\hline
\end{tabular}

than 1\%. Eichhornia crassipes was only found in wetland but due to its maximum coverage over the water bodies had limited the water availability for wild animals in the area

\section{Discussion}

Despite the small isolated forest patch, the area had recorded a relatively higher number of IAPS. The area had recorded 22 IAPS from 12 families out of total 26 species recorded in Nepal (Shrestha et al. 2017; Ghimire et al. 2020) which is more than $80 \%$ of IAPS recorded in the country. The diversity of IAPS in the study site was found higher in comparison to Parsa National Park situated near the study area where only 14 IAPS representing 5 families were recorded (Chaudhary et al. 2020). Pathak et al. 2021 recorded 20 IAPS in urban areas of Pokhara Valley. Mavimbela et al. 2018 concluded that forest patches with a high buffer matrix of residential and industrial surroundings have a high diversity of IAPS. The study area was also surrounded by densely populated residential area and had combination of different habitat type made favourable to spread the higher number of IAPS in the area.

Lowe et al. 2000 mentioned four species (Chromolaena odorata, Eichhornia crassipes, Lantana camara, and Mikania micrantha) as the world's 100 worst invasive species. Shrestha 2019 ranked Chromolaena odorata as most problematic to Terai and Siwalik region followed by Michenia micrantha and Lantana camara. The findings of the present study also support the statement. Present study ranked M. micrantha as the first followed by C. odorata at the second and L. Camara in the third. Similarly, all seven species were recorded in the study areas which were listed among the seven worst invasive alien plant species of Asia Pacific 
Regions (Sankaran et al. 2005). Tiwari et al. 2005 assessed the invasiveness of 21 IAPS and found six species as having high invasion rates, impacts, difficulty to control and distribution; namely, Ageratina adenophora, Chromolaena odorata, Lantana camara, Mikania micrantha, Eichhornia crassipes, and Ipomoea carnea. Presence of all these IAPS made the area highly susceptible for ecological degradation.

Wetland is rich in the case of invasive species and other weeds due to the availability of suitable conditions and high nutrient content (Kasulo, 2000). Eichhornia crassipes is the most problematic species that has invaded most wetlands of the Terai and mid-hills (Shrestha 2016; Tiwari et al. 2005). Six species were recorded by Shrestha (2016) namely Pistia stratiotes, Leersia hexandra, Myriophyllum aquaticum, Alternanthera philoxeroides, Ipomoea carnea, and Eichhornia crassipes, and seven species by Tiwari et al. 2005. As river side was also included in wetland for this study, additional four species namely Mimosa pudica, Ageratum houstonianum, Mikania micrantha and Parthenium hysterophorus were recorded in present study.

Invasive alien plant species were found mostly in open canopy, degraded forest and open land where light penetration is high (Ghimire et al. 2020). The present study identified the distributions of IAPS more in marginal, disturbed, and degraded areas. Forest area having closed canopy cover act as the physical barriers to the dispersal pathways and prevailing light and moisture condition act as environmental barriers for the establishment of alien plant species (Mavimbela et al. 2018). Open canopy reduces the barriers of seed dispersal and growth of the early successional species due to high penetration of light under forest. (Lawes et al. 2004). Tiwari et al. 2005 also concluded that disturbed, open, and marginalized areas of forests host more IAS rather than undisturbed or closed forests. Fugii et al. (2008) reported a high level of invasion near the settlements and this study also identified the maximum number of IAPS in the settlement area in comparison to forest, grassland and other habitat types. In forest areas including shrub lands, the most troublesome species are Ageratina adenophora, Lantana camara, Chromolaena odorata, and Mikania micrantha (Shrestha et al. 2017; Bhatta et al. 2020). This study also supports the findings with Shrestha et al. (2017) that Mikania micrantha, Chromolaena odorata, Lantana camara had the highest IVI value. IAPS such as Ageratina adenophora, Chromolaena odorata, Mikania micrantha, Lantana camara, and Hyptis suaveolens are serious IAPS disrupting forests and shrublands in Nepal (Tiwari et al. 2005; Shrestha 2016).

\section{Conclusion}

A total of 22 species of IAPS invaded the study area. Mikania micrantha, Chromolaena odorata, Lantana camara, Ageratina houstonianum were found to be most widely invaded. M. micrantha had highest abundance in forest area whereas Eichhornia crassipes in wetland and Parthenium hysterophorus in settlement areas. Due to presence of all identified most troublesome species for forestland and wetlands, the area was found in high level of threats for its ecological and environmental services. Periodic assessment of established plant species and the compilation of a prioritized list of invasive alien plant species are two practical ways for managing the invasive alien plant species (Pathak et al. 2021). This study has provided the baseline information regarding the IAPS however the impact of these IAPS over the ecological and environmental services has yet to be investigated. Impact analysis and possible management interventions have been identified as the area for further study.

\section{Acknowledgement}

We would like to acknowledge Institute of Forestry, Hetauda Campus; anonymous reviewers from the forestry:Journal of institute of Forestry,Nepal and very thankful to our friends Anita Bhattarai and Puspa Lamsal for help during data collection. 


\section{References}

Bhatta, S., Joshi, L. R., \& Shrestha, B. B. (2020). Distribution and impact of invasive alien plant species in Bardia National Park, western Nepal. Environmental Conservation, 47(3), 197-205.

Bisht, N., Joshi, S., Shrestha, B. B., Yi, S., Chaudhary, R. P., Kotru, R., \& Wu, N. (2016). Manual on invasive alien plant species in Kailash Sacred Landscape-Nepal. Manual on invasive alien plant species in Kailash Sacred LandscapeNepal.

Budha, P.B. (2013). Invasive alien species: Animals: In: Biological diversity and conservation (eds.) P.K. Jha, F.P. Neupane, M.L. Shrestha and I.P. Khanal. Nepal Academy of Science and Technology, Khumaltar, Lalitpur. Nepalpedia series 2, pp. 389-39

Cadotte, M. W., Yasui, S. L. E., Livingstone, S., \& MacIvor, J. S. (2017). Are urban systems beneficial, detrimental, or indifferent for biological invasion?. Biological invasions, 19(12), 3489-3503.

Chaudhary, R., Shrestha, B. B., Thapa, H., \& Siwakoti, M. (2020). Status and impacts of invasive alien plant species in Parsa National Park, central Nepal. Banko Janakari, 30(1), 21-31.

Davis, M.A., and Thompson, K.( 2000). Eight ways to be a colonizer; two ways to be an invader: a proposed nomenclature scheme for invasion ecology. Bulletin of the ecological society of America, 81(3), pp.226-230.

Ehrenfeld, J. G. (2010). Ecosystem consequences of biological invasions. Annual review of ecology, evolution, and systematics, 41, 5980.

Fugii, Y., Kurokawa, S. and Hiradate, S. (2008). Evolution of Invasive Alien Plants by modified FAO-WRA (2005): Importance of Allelopathy in Weed Risk Assessment. In New York, USA: Fifth Congress on Allelopathy. Saratoga Springs (pp. 73-74).

Gorgens, A.H.M. and Van Wilgen, B.W. (2004). Invasive alien plants and water resources in South Africa: current understanding, predictive ability, and research challenges: Working for Water. South African Journal of Science, 100 (1), pp.27-33.

Ghimire, M.D., Sharma (Dhakal), K. and Saud, D.S. (2020). Invasive Alien Species of Nepal. Government of Nepal. Ministry of Forest and Environment, Department of Plant
Resources. (In Nepali)

Lelmini M. R. and Sankaran K.V.,( 2021). Invasive Alien Species: A Prodigious Global Threat in the Anthropocene: In Invasive Alien Species Observations and Issues from Around the World (eds.) Pullaiah T. and M R Lelmini. John Wiley \& Sons Ltd.

Lawes, M. J., Macfarlane, D. M., \& Eeley, H. A. C. (2004). Forest landscape pattern in the KwaZulu-Natal midlands, South Africa: 50 years of change or stasis? Austral Ecology, 29, pp. 613-623.

Lowe, S., Browne, M., Boudjelas, S., \& De Poorter, M. (2000). 100 of the world's worst invasive alien species: a selection from the global invasive species database (Vol. 12). Auckland: Invasive Species Specialist Group.

Luque, G.M., Bellard, C., Bertelsmeier, C., Bonnaud, E., Genovesi, P., Simberloff, D. and Courchamp, F. (2014). The 100th of the world's worst invasive alien species. Biological invasions, 16(5), pp.981-985.

Kasulo, V. (2000). 10. The impact of invasive species in African lakes. The economics of biological invasions, 183

Mack, R.N., Simberloff, D., Mark Lonsdale, W., Evans, H., Clout, M. and Bazzaz, F.A. (2000). Biotic invasions: causes, epidemiology, global consequences, and control. Ecological applications, 10 (3), pp. 689-710.

Maraseni, T.N., J. Maroulis, and G. Cockfield. (2008). An estimation of willingness to pay for asparagus (Asparagus racemosus Willd.) collectors in Makwanpur District, Nepal. Journal of Forest Science. 54(3), pp. 31-37

Mavimbela, L.Z., Sieben, E.J.J. \& Procheş, Ş. (2018). Invasive alien plant species, fragmentation and scale effects on urban forest community composition in Durban, South Africa. N.Z. J. of For. Sci. 48 (19), pp. 1-14. pphttps://doi. org/10.1186/s40490-018-0124-8

Murphy, S.T., Subedi, N., Jnawali, S.R., Lamichhane, B.R., Upadhyay, G.P., Kock, R. and Amin, R. (2013). Invasive Mikania in Chitwan National Park, Nepal: the threat to the greater onehorned rhinoceros Rhinoceros unicornis and factors driving the invasion. Oryx, 47 (3), pp. 361-368.

Pandey M., Thapa-Magar K. B., Poudel B.S., Davis T. S., and Shrestha B. B. (2020). Plant Invasion Research in Nepal: A Review of Recent National Trends. Weeds - Journal of AsianPacific Weed Science Society, 2 (2). pp. 16-33. 
Pathak, H.N., Bhuju, D.R., Shrestha, B.B. and Ranjitkar S.,(2021). Impacts of invasive alien plants on ecosystem services of Ramsar Lake cluster in middle mountain Nepal. Global Ecology and Conservation, 27 (15).

Rai, I.D., Adhikari, B.S. and Rawat, G.S. (2012). Floral diversity along with sub-alpine and alpine ecosystems in Tungnath area of Kedarnath wildlife sanctuary, Uttarakhand. Indian Forester, 138(10), pp. 927-940.

Rai, R.K. and Scarborough, H. (2012). Valuing the Damage Caused by Invasive Plant Species in a Low-income Community in Nepal. SANDEE.

Sankaran, K.V., Murphy, S.T. and Sreenivasan, M.A. (2005). When good trees turn bad: the unintended spread of introduced plantation tree species in India. The unwelcome guests.

Shrestha, B.B. (2016). Invasive alien plant species in Nepal. Frontiers of botany. Central Department of Botany, Tribhuvan University, Kirtipur, Kathmandu, pp. 269-284.

Shrestha, B. B., Siwakoti, M., \& Ranjit, J. (2017, May). Status of invasive alien plant species in Nepal. In Conservation and utilization of agricultural plant genetic resources in Nepal (Joshi BK, KC HB, Acharya AK.(eds). Proceedings of 2nd National Workshop, 22-23
May 2017 Dhulikhel.

Shrestha, B. B. (2019). Management of invasive alien plants in Nepal: Current practices and future prospects. In Tropical ecosystems: Structure, functions and challenges in the face of global change (pp. 45-68). Springer, Singapore.

Shrestha, B.B., Joshi, S., Bisht, N., Yi, S., Kotru, R., Chaudhary, R.P. and Wu, N. (2018). Inventory and impact assessment of invasive alien plant species in Kailash Sacred Landscape.

Štajerová, K., Šmilauer, P., Brůna, J. et al. (2017). Distribution of invasive plants in urban environment is strongly spatially structured. Landscape Ecol 32, pp. 681-692. https://doi. org/10.1007/s10980-016-0480-9

Timsina, B., Shrestha, B.B., Rokaya, M.B. and Münzbergová, Z. (2011). Impact of Parthenium hysterophorus $L$. invasion on plant species composition and soil properties of grassland communities in Nepal. FloraMorphology, Distribution, Functional Ecology of Plants, 206 (3), pp.233-240.

Tiwari, S., Adhikari, B., Siwakoti, M. and Subedi, K. (2005). An inventory and assessment of invasive alien plant species of Nepal IUCN. The World Conservation Union, Kathmandu. 